\title{
THE EFFECT OF SOCIAL MEDIA MARKETING, TRUST BRAND, AND WORD OF MOUTH ON PURCHASE DECISIONS (CASE STUDY AT REAL B DISTRO SURABAYA).
}

\author{
Risky Bahrudin Yusuf ${ }^{1}$, Sengguruh Nilowardono ${ }^{2}$ \\ Riskybahrudinyusuf@gmail.com¹, sengguruh@narotama.ac.id ${ }^{2}$ \\ Narotama University, Faculty of Economics and Business, Departement of Management Arief Rachman Hakim \\ Street Number 51, Sukolilo, Surabaya $60117^{1,2}$
}

\begin{abstract}
The intention of consumer purchases is the willingness of a product to buy the goods they want. this is a strong determinant in the purchase of a product or brand. Therefore this study aims to analyze whethervariables social media marketing, brand trust, word of mouth can influence purchasing decisions to buy various Persebaya attribute products that are sold at Real B Distro Surabaya. This research is quantitative research with a sample of 160 respondents. Furthermore, the data were analyzed using multiple linear regression analysis techniques and classical assumption tests. The results showed that the three hypotheses proposed had a significant and supportive effect.
\end{abstract}

Keywords: social media marketing, brand trust, word of mouth, purchasing decisions

\section{INTRODUCION \\ Background}

Football is the sport most loved by the entire world community and often times, the popularity of football can attract many new fans who make it becoming one of the global sports (fifa.com, 2012). but behind the game of soccer, soccer saves a very profitable business potential. Many business opportunities that can be developed in the world of soccer. one of them is merchandise or knick knacks from famous soccer clubs, both national and international football clubs. In Indonesia, the football merchandise creative industry is still in the process of development, there are only a few large clubs that have large numbers of supporters and fanatics, such as Persebaya, Persib, Persipura Persija and Sriwijaya (Republik.co.id, 2013). This encourages club management and supporters to maximize the marchandise creative industry. One of the soccer clubs from Surabaya named Persebaya has fanatical fans named Bonek or known as Bondo Nekat

Junaedi (2012) who said that supporters in Indonesia did not use clothes and attributes that were uniform in color with the teams supported. Then in 1998 the Persebaya supporters began to conceive using clothes that matched the color of the team they supported, namely green so that Bonek became Indonesia's first supporter who initiated the use of the same color on a supported team so as to become an identity and differentiate from other supporters.

With the emergence of supporters who wear uniform attributes when supporting their team, making MSMEs and Street Vendors in Indonesia open a business that is engaged in clothing and accessories for supporters. Because of the many interests of supporters who buy attributes to support their teams, business competition arises in capturing market share. Therefore an entrepreneur must be able to increase consumer buying interest. According to Kotler (2005) consumer buying interest will arise automatically if consumers already feel interested or give a positive response to what is offered by the seller

Distribution stores or commonly called distributions are generally small and medium industries with independent brands developed by young people . Distros in Indonesia began to be known since the mid-1990s in the city of Bandung. The initial distribution was only a small shop that sold items that were not found in other stores, such as shoopingmall, The clothing boom that occurred in 2003 made the growth of distributions in Indonesia more and more. Now in a number of major cities in Indonesia the distribution business is experiencing significant development. In Bandung, there are distributions that sell a variety of fashion products easily found. The prices pegged are not too expensive, adjusting to the purchasing ability of consumers who come from groups of young people (Muthohirin, 2014). Distro sells various kinds of products with various designs and motives and distributions also provide products that are unique to their community.

In Surabaya there are also distributions that sell various kinds of products, but what is becoming a trend now is that distro business people develop their business by making product attributes of soccer clubs that can make the identity of a football supporter. The rise of soccer clubs originating from Surabaya opens opportunities for business people, so competition is getting tougher. 
One example is the Real B Distro distribution located on J1. Jolotundo No.53, Surabaya. This distribution was established in 2012 until now and is very much in demand by customers, most of whom are supporters of the Persebaya Football Team Surabaya. "The idea of setting up this shop was to make it easier for Bonek to buy accessories because at that time getting accessories was still difficult because there was no one to sell. There were attribute sellers, but only street vendors. And the first distro shop concept was drafted. "explained Yudha, one of the distribution owners to reporters (Mutdlikha, 2016). Real B distributions are distributions that make the concept of selling a variety of attributes Persebaya into the store

at that time there has been no distributions that sell Persebaya and have brand attributes., Of the goods sold in the Real B distributions green. Products sold are various such as: shirts, jackets, bracelets, hats, belts, bags, scarves, stickers and other accessories. In the increasingly fierce business competition and the many distributions that sell the same product, distro owners must be able to attract consumer buying interest in order to survive and compete. Therefore Real B Distro must know consumer behavior that influences a buying interest point.

One factor to attract the attention of consumers who will be interested in buying products from Real B Distro is that entrepreneurs must know a person's personality by knowing social media marketing. is the activity of using social media marketing as a means to market products / services. According to kotler and keller (2012: 5) "Marketing is a social process that individuals and groups obtain what they need and want through, creating, and freely exchanging products and services of value with others ", marketing is a social process whereby individuals and groups obtain what they need and want to create by creating, offering, and freely exchanging valuable products and services with others.

According to the AMA (American Marketing Association) quoted by Kotler and Keller (2012: 5) the definition of marketing is "marketing is the activity, set of institutions and processes for creating, communicating, delivering, and exchanging offers that have value for customers, clients, partners, and society at large ". Marketing is an organizational function and a series of processes for creating, communicating, and giving value to customers and for managing customer relationships in a way that benefits the organization. From the definition above can be concluded that marketing is important for the success of a company.

Brand Trust is the feeling of security that consumers have as a result of their interaction with a brand, which is based on the perception that the brand is reliable and is responsible for the interests and safety of consumers. According to Hermawan Kertajaya (2004: 11), Marketing Icon of Indonesia, brands are an indicator of the value offered to customers by strengthening their loyalty. The American Marketing Association defines a brand as a name, term, sign, symbol, or all combination design, which is intended to define the goods or services of a person or group of sellers and to distinguish them from competitors' goods or services. According to Murthy (in Kertajaya, 2009: 11) from the point of view of the company, brand trust is a brand that has succeeded in creating a memorable brand experience in consumers that is sustainable in the long term, based on integrity, honesty and politeness of the brand. According to Guviez \& Korchia (in Ferinnadewi, 2008: 148) from the point of view of consumers, brand trust is a psychological variable that reflects a number of initial assumptions involving credibility, integrity, and benevolence, which are attached to certain brands.

According to Hasan (2010), word of mouth is a compliment, recommendations and comments from customers around their experience of services and products that really affect customer decisions or their buying behavior. Word of mouth can shape customers' trust. Whereas According to Sernovitz (2009), word of mouth is a conversation that naturally occurs between people. Word of mouth is the talk of genuine consumers. According to Ivanovic and Collin (2004), "word of mouth communication is an informal channel of communication such as friends and neighbors, coworkers and family members." According to Sernovitz (2009), "word of mouth is so effective because the origin of trust is from people who do not benefit from their recommendations. "

So the three variables above social media marketing, brand trust, and word of mouth have positive effects and some have a negative influence on buying interest. By looking at this, it needs to be examined further. Looking at the above phenomenon, I as a final-year student of Narotama University intends to conduct research with the title "SOCIAL EFFECT OF MEDIA MARKETING, BRAND TRUST AND WORD OF MOUTH ON PURCHASE DECISIONS (REAL B DISTRO CASE STUDY SURABAYA)"

\section{Research Objectives}

1.) To analyze positive influences and significant social media marketing towards decisions purchesing

2.) To analyze the positive and significant influence of brand trust decisions purchasing

3.) To analyze the positive and significant influance of word of mouth on purchasing decisions

4.) To analyze the positive and significant influance social media marketing,brand trust, word of mouth on purchasing decisons

\section{FRAMEWORK}




\section{SOCIAL MEDIA MARKETING}

According to Gunelius (2011: 10) social media marketing is a form of direct or indirect marketing used to build awareness, recognition, memory, and actions for brands, businesses, products, people, or other entities and carried out using social web tools such as blogging, microblogging, social networking, social bookmarking, and content sharing. Social media marketing is a process that encourages individuals to promote through their websites, products, or services through online social channels and to communicate by using a much larger community that is more likely to do marketing than through traditional advertising channels (Weinberg, 2009: 3-4). Social media marketing is a form of online advertising that uses the cultural context of social communities including social networks, virtual worlds, social news sites, and social opinion sharing sites to meet communication goals (Tuten, 2008: 19)

\section{BRAND TRUST}

According to Murthy ( in Kertajaya, 2009: 11) from the point of view of the company, brand trust is a brand that successfully creates a memorable brand experience in consumers that is sustainable in the long term, based on integrity, honesty and politeness of the brand. According to Guviez \& Korchia (in Ferinnadewi, 2008: 148) from the point of view of consumers, brand trust is a psychological variable that reflects a number of initial assumptions involving credibility, integrity, and benevolence, which are attached to certain brands

\section{WORD OF MOUTH}

According to Hasan ( 2010), word of mouth is a compliment, recommendations and comments of customers around their experience of service and product that really affects customer decisions or their buying behavior. Word of mouth can shape customers' trust.

\section{PURCHASE DECISIONS}

According to Kotler (2009) the buying decision is: "several stages carried out by consumers before making a product purchase decision".

\section{CONCEPTUAL FRAMEWORK}

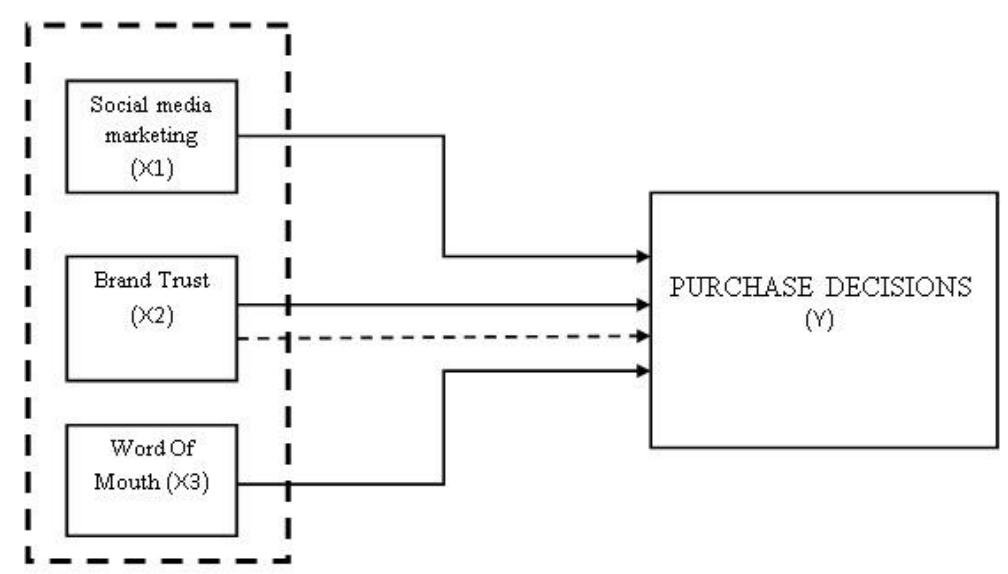

\section{HYPOTHESIS}

THE HYPOTHESIS IN THIS STUDY ARE:

H1: Social media marketring has a positive and significant effect on purchasing decisions.

$\mathrm{H} 2$ : Brand trust has a positive and significant effect on purchasing decisions.

H3: Word of mouth has a positive and significant effect on purchasing decisions.

H4: social media marketing, brand trust and word of mouth have a significant effect on purchasing decisions

\section{RESEARCH METHODS}

Approach of this research uses a quantitative approach. According to Sugiyono (2013) the quantitative method is a study that uses samples and numerical data or data in the form of numbers to examine certain populations or samples, sampling techniques are generally done randomly, data collection uses research instruments, quantitative / statistical analysis with the aim to test what has been set.

\section{Population and Samples Types, Sources, Data Collection Techniques Data}

types used in this study are quantitative data because in collecting information using questionnaires directly distributed to consumers Real B Distro Surabaya 


\section{Research Variables}

Operational variables are explanations of everything that has been determined by researcher (variable), so that it can be observed and measured by the author in order to obtain information and then draw conclusions. The variables used in this study are two parts, namely:

1) Free variables (independent variables / exogenous variables) are variables that affect the dependent variable (positive variable) both positively and negatively. In this study, the independent variables are: social media marketing (X1), brand trust (X2), and Word of mouth (X3).

2) Bound variables (dependent variables) are the first variables influenced by independent variables and other variables. In this study, the dependent variable is a purchasing decision (Y)

\section{Test Reliability and Validity}

Test Reliability

Reliability is a level that measures the consistency of results if done repeatedly in a characteristic. According to Sumadi Suryabrata (2004) reliability shows how far the measurement results with these tools can be trusted. The measurement results must be reliable in the sense that they must have a level of consistency and stability. Reliability testing can be calculated using theformula Cronbach Alpha.

\section{Hasil Uji Reliabilitas}

Reliability Statistics

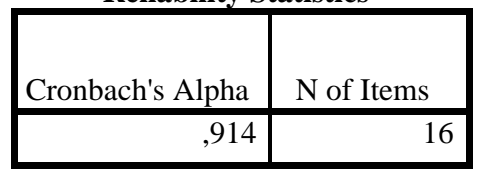

Source: SPSS output data (2019) Can be seen from table 4.9 above, this research data has cronbach's alpha 0.914 and is above 0.60 , then the data of this study can be declared reliable and trustworthy

\section{Test Validity}

Validity is a level that measures the characteristics that exist in the phenomenon in the study. According to Aritonang (2007) the validity of an instrument is related to the ability of the instrument to measure or reveal the characteristics of the variables intended to be measured. An instrument is said to be valid if it is able to uncover data from variables that are properly examined. Whereas it is said to be invalid if it is not able to reveal data from the variables examined correctly

VALIDITY TEST RESULTS

\begin{tabular}{|c|c|c|c|c|}
\hline No. & Indikator/Variabel & Korelasi & r Tabel & Keterangan \\
\hline $\begin{array}{l}1 . \\
2 . \\
3 .\end{array}$ & $\begin{array}{c}\text { Social Media Marketing } \\
\text { X1.1 } \\
\text { X1.2 } \\
\text { X1.3 } \\
\end{array}$ & $\begin{array}{r}455 \\
548 \\
558\end{array}$ & $\begin{array}{l}0,1305 \\
0,1305 \\
0,1305\end{array}$ & $\begin{array}{l}\text { Valid } \\
\text { Valid } \\
\text { Valid }\end{array}$ \\
\hline $\begin{array}{l}1 . \\
2 . \\
3 . \\
4 . \\
5 .\end{array}$ & $\begin{array}{c}\text { Brand Trust } \\
\text { X2.1 } \\
\text { X2.2 } \\
\text { X2.3 } \\
\text { X2.4 } \\
\text { X2.5 }\end{array}$ & $\begin{array}{l}603 \\
729 \\
651 \\
722 \\
457\end{array}$ & $\begin{array}{l}0,1305 \\
0,1305 \\
0,1305 \\
0,1305 \\
0,1305\end{array}$ & $\begin{array}{l}\text { Valid } \\
\text { Valid } \\
\text { Valid } \\
\text { Valid } \\
\text { Valid }\end{array}$ \\
\hline $\begin{array}{l}1 . \\
2 . \\
3 . \\
4 .\end{array}$ & $\begin{array}{c}\text { Word Of Mouth } \\
\text { X3.1 } \\
\text { X3.3 } \\
\text { X3.3 } \\
\text { X3.4 }\end{array}$ & $\begin{array}{l}559 \\
689 \\
568 \\
484\end{array}$ & $\begin{array}{l}0,1305 \\
0,1305 \\
0,1305 \\
0,1305\end{array}$ & $\begin{array}{l}\text { Valid } \\
\text { Valid } \\
\text { Valid } \\
\text { Valid }\end{array}$ \\
\hline $\begin{array}{l}1 . \\
2 . \\
3 . \\
4 .\end{array}$ & $\begin{array}{c}\text { Keputusan Pembeli } \\
\text { Y.1 } \\
\text { Y.2 } \\
\text { Y.3 } \\
\text { Y.4 }\end{array}$ & $\begin{array}{l}647 \\
718 \\
680 \\
558\end{array}$ & $\begin{array}{l}0,1305 \\
0,1305 \\
0,1305 \\
0,1305\end{array}$ & $\begin{array}{l}\text { Valid } \\
\text { Valid } \\
\text { Valid } \\
\text { Valid }\end{array}$ \\
\hline
\end{tabular}

Source: Processed SPSS Output Data (2019)

Based on Table 4.10 shows that all indicators used to measure social media marketing variables (X1), brand trust (X2), and word of mouth (X3), and buyer decisions (Y) used in this study have correlation 
coefficients or rhitung which greater than rtable $=0.1305$ (rtable value for $n=160$ ). So that all these indicators are valid

\section{Multicollinearity}

test aims to test whether the regression model found a correlation between independent variables. If multicollinearity is found, then variable variable coefficients are uncertain and errors become infinite Ghozali (2005). The multicollinearity test in this study can be seen as follows.

\section{Multicollinearity Test Results}

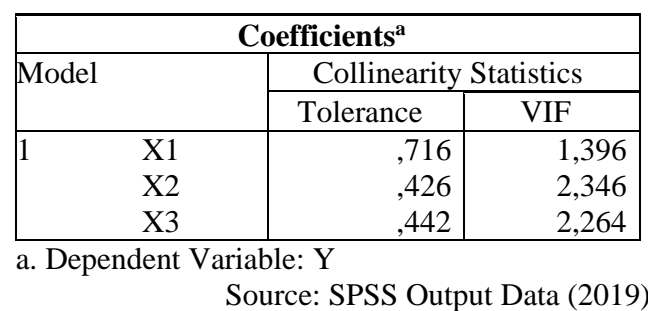

Based on table 4.16 it can be seen that the regression model does not experience multicollinearity problems. This can be seen in the tolerance value of each independent variable greater than 0.1 . The VIF calculation results also show that the VIF value of eachindependent variable is less than 10 . So it can be concluded that there is no multicollinearity between the independent variables in the regression model.

\section{Heteroscedasticity}

Test Heteroscedasticity test aims to test whether in the regression model there is an inequality of variance from the residual one observation to another observation (Ghozali, 2005).

Scatterplot

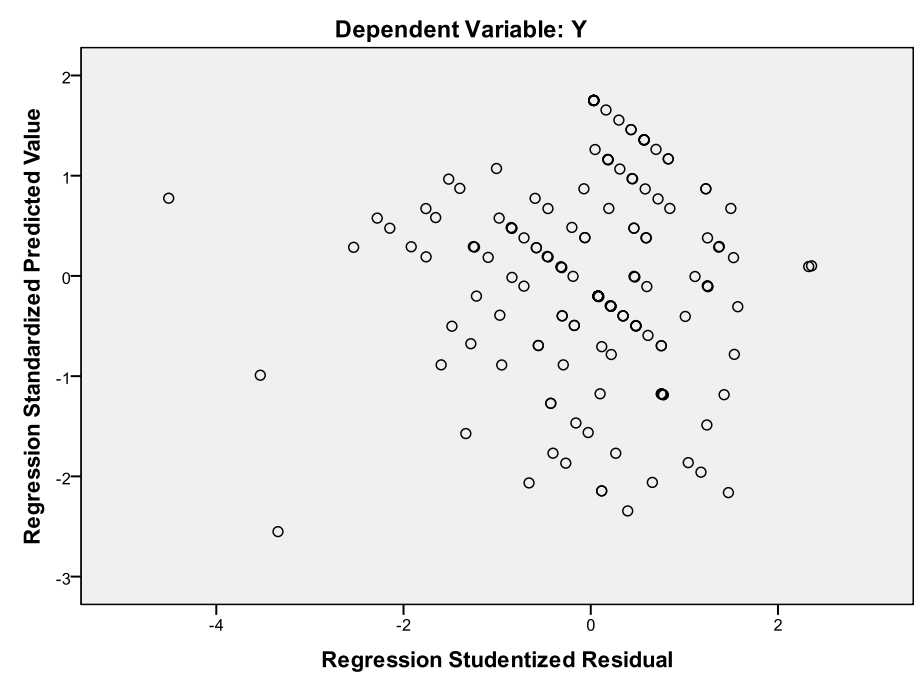

Source: SPSS Output Data (2019)

From the Scatterplot graph in Figure 4.3 it can be seen that the points spread randomly, both above and below the zero on the $\mathrm{Y}$ axis. It can be concluded that the model in this study fulfills the requirements of homoskedasticity or does not occur symptoms of heteroscedasticity.

\section{Normality}

The normality Testtest aims to test whether in the regression model the disturbance or residual variable has a normal distribution. It is known that the $\mathrm{t}$ and $\mathrm{F}$ tests assume that the residual value follows a normal distribution. There are two ways to detect whether residuals are normally distributed or not, namely graph analysis and statistical tests (Ghozali, 2005). 
Normality test result

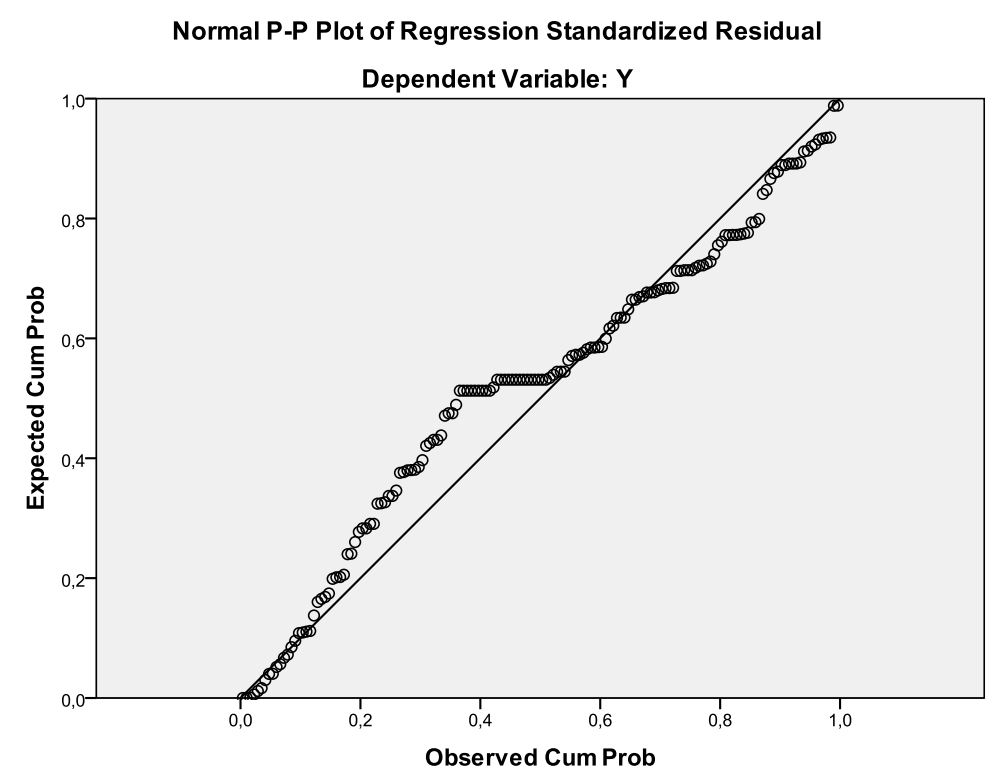

Source: SPSS Output Data (2019)

In Figure 4.4 it can be seen that the standardized normal probability plot of regression shows a normal graph pattern. This can be seen from the points that spread around the diagonal line and the diagonal line from the lower left to the top right. Then it can be concluded that the regression model is feasible because it meets the assumptions of normality.

\section{REFERENCES}

Amron, A. (2018). The Influence of Image Brands, Brand Trusts, Product Quality, and Price on the Consumer's Buying Decision of MPV Cars, 14(13), 228-239. https://doi.org/10.19044/esj.2018.v14n13p228

Diyos Nugraha Eka Putra. (2015). THE EFFECT OF WORD OF MOUTH ON PURCHASE DECISIONS ON GEMPOL BREAD CAFE AND ANJIS COFFEE OF THE INFLUENCE OF WORD OF MOUTH ON BUYING DECISION IN CAFE ROTI, 2(1), 758-763.

Gunelius, S. (2011). 30 Minute Social Media Marketing. United States: McGraw Hill.

Iblasi, WN, Bader, DMK, \& Al-qreini, SA (2016). The Impact of Social Media as a Marketing Tool on Purchasing Decisions (Case Study on SAMSUNG for Electrical Home Appliances), 4(1), 14-28.

Khalid, S., Ahmed, MA, \& Ahmad, Z. (2012). Word-of-Mouth Communications: A Powerful contributor to Consumers Decision-making in Healthcare Market, 2(5), 55-64.

Khatib, F. (2016). The Impact of Social Media: Characteristics of Purchase Decision Empirical Study of Saudi Arabia Ibn Rushd College Need for Literature Review:, 7(4), 41-50.

Kindangen, Keles Dikna Maria Paulus Rumokoy, FS (2016). THE EFFECT OF ELECTRONIC WORD OF MOUTH ON BUYING DECISION CONSUMER IN LAZADA, 4(1). 
Mahuda, FD (2017). Effect of brand personality and brand trust on purchasing decisions (Case Study of Meccanism Boutique). Islamic Economics, 8(2), 151-167.

Pratama, FA (2017). THE EFFECT OF TRUST BRAND AND PRODUCT QUALITY ON THE DECISION OF PURCHASING CONSUMERS OF HONDA BEAT MOTORCYCLE PRODUCTS IN KARANGPILANG KECAMATAN, SURABAYA CITY, (1411), 111-124.

Rembon, A., Mananeke, L., \& Gunawan, E. (2017). THE EFFECT OF WORD OF MOUTH AND PRODUCT QUALITY ON PURCHASE DECISIONS IN. KANGZEN KENKO INDONESIA IN MANADO THEINFLUENCE OF WORD OF MOUTH AND PRODUCT QUALITY OF PURCHASING Faculty of Economics and Business, Department of Management, Sam Ratulangi University M. Sarimin, 5(3).

Zanjabila, R., \& Hidayat, R. (2017). ANALYSIS OF THE EFFECT OF SOCIAL MEDIA MARKETING ON PURCHASE DECISIONS BANDUNG TECHNO PARK (STUDY ON CUSTOMER BANDUNG TECHNO PARK 2017) ANALYSIS OF SOCIAL MEDIA MARKETING ON PURCHASING DECISIONS OF TECHNO PARK (STUDY ON BANDUNG TECHNO PARK CUSTOMERS Techno Park area is one attempt BTP to bring profit. In every year btp would not have difficulty to reach the target packing the room of office by the tenant. It can be said that BTP has a problem of sales growth and decisions of the purchase of consumers. In this research writer the influence of marketing like social media via the purchase decision of a tenant in Bandung Techno Park. Research is called "Analysis of Social Media Marketing on Purchasing Decisions of Bandung Techno Park". A theory that is used in this research uses the quantitative population of Bandung Techno Park. Sample used is the consensus. The data collection method by using questionnaires and analysis of data use linear regression simple. Theresults 10

of the study showed that attributes products had a significant impact with the regression equation is $\mathrm{y}=$ $5,675+0,209 x$. To test square shows the 0,249 , this can be explained that the influence of social media marketing decisions is $24,9 \%$ and the rest of $75,1 \%$ influenced other factors such as facilities available , prices and environment which are subjects in this study. Keywords: social media marketing and purchase decisions., 3(2), 368-375. 